\title{
ogopaedica
ogziensia
}

$\mathrm{Nr} 3$ (2019)

DOl: http://dx.doi.org/10.18778/2544-7238.03.14

Ewa Gacka*

\section{Recenzja: Henryk Panusz, Spacer w zoo: wiersze i zagadki z quizem, Wydawnictwo Henryk Panusz, Łódź 2018}

Na pomoc edukacyjną Spacer w zoo: wiersze i zagadki z quizem autorstwa Henryka Panusza składa się książeczka z rymowanymi zagadkami (dotyczącymi mieszkańców tytułowego zoo), quiz sprawdzający wiedzę dzieci na temat wyglądu, środowiska i trybu życia wybranych zwierząt oraz sześć kompletów puzzli z dołączonymi wzorami, na których przedstawiono bohaterów poszczególnych wierszowanych zagadek.

Zestaw jest adresowany przede wszystkim do dzieci w wieku przedszkolnym i wczesnoszkolnym, ale sięgnąć po niego mogą także nieco starsi czytelnicy. Stanowi dobrą okazję do wspólnej lektury i kształcącej zabawy zarówno dla dzieci, jak i ich rodziców czy opiekunów. Podczas zajęć dydaktycznych skorzystać z niego mogą również nauczyciele wychowania przedszkolnego oraz edukacji wczesnoszkolnej. Może on przydać się w pracy terapeutycznej także takim specjalistom jak pedagodzy, psycholodzy czy logopedzi.

Z prezentowanej pomocy można korzystać w całości lub z wybranych jej części - w zależności od wieku, chęci i możliwości psychofizycznych poszczególnych dzieci. I tak w przypadku najmłodszych odbiorców najbardziej zasadne będzie czytanie przez rodziców bądź opiekunów wierszyków i na ich podstawie opowiadanie o zwierzątkach, zadawanie pytań do wysłuchanych przez dzieci treści, rozpoznawanie zwierząt na ilustracjach. Dla starszych atrakcyjne może być układanie puzzli czy rozwiązywanie quizu z pomocą dorosłych. W przypadku najstarszych dzieci (już

\footnotetext{
* Uniwersytet Łódzki, Wydział Filologiczny, Zakład Dialektologii Polskiej i Logopedii, ul. Pomorska 171/173, 90-236 Łódź, e-mail: ewa.gacka@uni.lodz.pl, https://orcid.org/0000-0002-1873-7487
} 
czytających i piszących) dobrym pomysłem będzie motywowanie do samodzielnego rozwiązania testu o zwierzętach, a w razie trudności do poszukania niezbędnych informacji w innych książkach bądź na stronach internetowych, do czego zachęca sam autor, podając konkretne adresy.

Rymowane wierszyki-zagadki w atrakcyjnej dla dziecka formie dostarczają podstawowych wiadomości na temat wybranych zwierząt i stanowią przygotowanie do planowanego spaceru po ogrodzie zoologicznym bądź przywołują wspomnienia $\mathrm{z}$ wizyty w zoo. Pomagają rozwijać wyobraźnię, pamięć słuchową, a także słownictwo. Mogą stać się punktem wyjścia do rozmów z dziećmi, kształtujących ich umiejętności dialogowe. Stanowią więc doskonały przykład pomocy, którą można wykorzystać w stymulowaniu zdolności językowych dziecka - i to zarówno rozwijającego się prawidłowo, jak i tego z pewnymi deficytami. Układanie puzzli (będących częścią zestawu edukacyjnego) rozwija wyobraźnię przestrzenną, koordynację wzrokowo-ruchową, spostrzegawczość oraz sprawność manualną.

W książeczce znalazło się miejsce na własne notatki lub rysunki dziecka, co sprawia, że zyskuje ona niepowtarzalny, spersonalizowany charakter. Zamieszczony w niej kupon konkursowy, którego prawidłowe wypełnienie (wpisanie odpowiedzi na pytania zawarte w quizie) i przesłanie do wydawnictwa pozwala na udział w losowaniu nagrody, stanowi dodatkową inspirację do zabawy.

Niewątpliwym walorem zestawu jest także to, że zachęca on do wspólnej zabawy i wspólnego spędzenia czasu przez dzieci i rodziców, a także pomaga w rozwoju nawyku czytania u najmłodszych. 